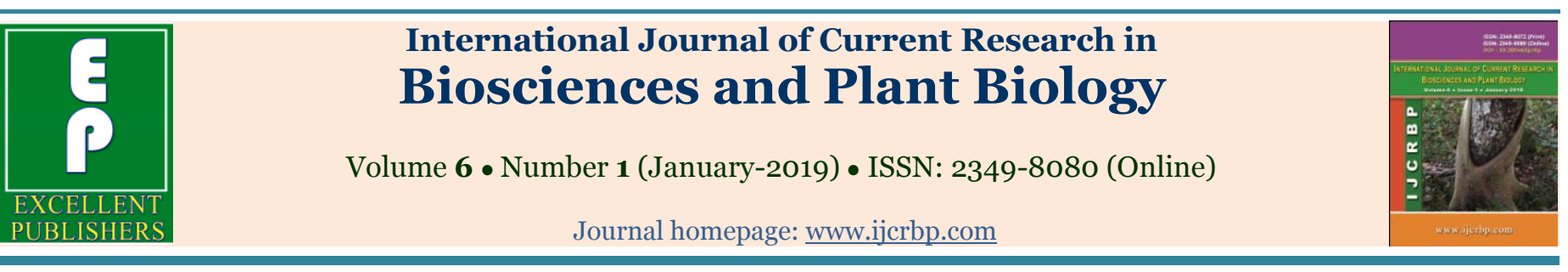

\title{
Invasive flora of Poondi stream, Kodaikanal, Tamil Nadu
}

\author{
P. Venkadeswaran*, K. Suresh and N. Vasudevan \\ P.G. and Research Department of Botany, Saraswathi Narayanan College, Madurai - 625 022, Tamil Nadu, India \\ *Corresponding author
}

\begin{tabular}{|c|c|}
\hline Article Info & ABSTRACT \\
\hline $\begin{array}{l}\text { Date of Acceptance: } \\
15 \text { December } 2018\end{array}$ & \multirow{4}{*}{$\begin{array}{l}\text { Invasive Species as an alien species which becomes established in natural or semi- } \\
\text { natural ecosystems or habitat, an agent of change and threatens native biological } \\
\text { diversity. A Comprehensive and exhaustive study on alien plants existing in Poondi } \\
\text { stream of Kodaikanal region for about } 9.5 \text { kilometer from Poondi dam to Kumboor } \\
\text { village was undertaken for a period of } 24 \text { months from January, } 2015 \text { to December, } \\
2016 . \text { By the current research work, it was recorded that a total of } 51 \text { alien species } \\
\text { belonging to } 45 \text { genera distributed among } 28 \text { families of angiospermic alien species. } \\
\text { Among } 51 \text { species of alien, dicotyledons were represented by } 41 \text { species of } 36 \text { genera } \\
\text { belonging to } 22 \text { families and monocotyledons by } 10 \text { species of } 9 \text { genera belonging to } 6 \\
\text { families. This paper concluded that impact of invasiveness created by these alien } \\
\text { species should controlled by planting native species into the natural forest area. }\end{array}$} \\
\hline $\begin{array}{l}\text { Date of Publication: } \\
\text { o6 January } 2019\end{array}$ & \\
\hline Keywords & \\
\hline $\begin{array}{l}\text { Invasive specie } \\
\text { Kodaikanal } \\
\text { Poondi stream }\end{array}$ & \\
\hline
\end{tabular}

\section{Introduction}

IUCN (International Union for Conservation of Nature and Natural Resources) defines "Invasive Species" as an alien species which becomes established in natural or semi-natural ecosystems or habitat, an agent of change and threatens native biological diversity. A taxon can be considered successfully naturalized after overcoming geographical, environmental and reproduction barriers, while an invasive species requires, in addition, overcoming dispersal barrier within the new region (Richardson et al., 2000). They are noxious and cause negative impact in environment, ecosystems, habitats, native biodiversity, economics and even human health (Khanna, 2009). Invasive species has faster rates of growth and biomass production compared to native species, higher competitive ability, high reproductive efficiency including production of a large number of seeds, efficient dispersal, vegetative reproduction, rapid establishment and other traits that help them adapt to new habitats (Sharma et al., 2005; Simberloff et al., 2005). On these aspects, there is an apparent need for a regional and national authentic database on invasive alien species for monitoring their spread and impact in various regions and for devising appropriate management strategies.

\section{Materials and methods}

\section{Description of the study stream - Poondi Geographical details}

The area of investigation - Poondi stream is lies between $77^{\circ} 18^{\prime} 14.3^{\prime \prime}-77^{\circ} 20^{\prime} 23.6^{\prime \prime}$ E longitude and $10^{\circ} 11^{\prime} 11.4^{\prime \prime}-10^{\circ} 14^{\prime} 20.9^{\prime \prime} \mathrm{N}$ latitude. The 
altitude of the study area ranged from 1200 to $2100 \mathrm{~m}$ above Mean Sea Level. Temperature of the study area was varied from $11.28^{\circ} \mathrm{C}$ to $20.78^{\circ} \mathrm{C}$. The area of investigation receives $122.80 \mathrm{~mm}$ and $171.7 \mathrm{~mm}$ of precipitation as minimum and maximum rainfall, during the study period (2015-16).

\section{Methodology}

A Comprehensive and exhaustive study on alien plants existing in Poondi stream of Kodaikanal region for about 9.5 kilometer from Poondi dam to Kumboor village was undertaken for a period of 24 months from January, 2015 to December, 2016. All the alien plants collected were botanically identified by referring Flora of Palni hills, (Matthew, 1999) and Flora of Tamil Nadu - a database (Narasimhan, 2006).

\section{Results and discussion}

By the current research work, it was recorded that a total of 51 alien species belonging to 45 genera distributed among 28 families of angiospermic alien species (Table 1). Among 51 species of alien, dicotyledons were represented by 41 species of 36 genera belonging to 22 families and monocotyledons by 10 species of 9 genera belonging to 6 families (Fig. 1).

Table 1. List of alien plants recorded from the study stream.

\begin{tabular}{|c|c|c|c|}
\hline Botanical Name & Family & Habit & Native region \\
\hline Acacia dealbata L. & Mimosaceae & Tree & Australia \\
\hline Achyranthes aspera L. & Amaranthaceae & Herb & South-East Africa \\
\hline Acmella calva (DC.) R.K.Jansen & Asteraceae & Herb & America \\
\hline Agave americana $\mathrm{L}$. & Agavaceae* & Shrub & Tropical America \\
\hline Ageratina adenophora (Spreng.) R.M. King \& H.Rob & Asteraceae & Shrub & Tropical America \\
\hline Ageratum conyzoides L. & Asteraceae & Herb & Tropical America \\
\hline Alnus nepalensis D. Don & Betulaceae & Tree & South-East Asia \\
\hline Asclepias curassavica L. & Asclepiadaceae & Shrub & Tropical America \\
\hline Bidenspilosa L. & Asteraceae & Herb & Tropical America \\
\hline Calceolaria gracilis Kunth & Scrophulariaceae & Herb & Tropical America \\
\hline Cardamine africana $\mathrm{L}$. & Brassicaceae & Herb & Africa \\
\hline Chenopodium ambrosioides $\mathrm{L}$. & Chenopodiaceae & Herb & Tropical America \\
\hline Chromolaena odorata (L.) R. M. King \& H. Rob. & Asteraceae & Shrub & Tropical America \\
\hline Cotoneaster buxifolius Lindl. & Rosaceae & Shrub & China \\
\hline Cymbopogon citratus (DC. ex Nees) Stapf. & Poaceae* & Herb & South-East Asia \\
\hline Cynodon dactylon (L.) Pers. & Poaceae* & Herb & Europe \\
\hline Cyperus difformis $\mathrm{L}$. & Cyperaceae* & Herb & Tropical America \\
\hline Cyperusiria L. & Cyperaceae* & Herb & Tropical America \\
\hline Erigeron karvinskianus DC. & Asteraceae & Herb & Tropical America \\
\hline Eucalyptus citriodora Hook. f. & Myrtaceae & Tree & Tropical Australia \\
\hline Eucalyptus globulus Labill. & Myrtaceae & Tree & Tropical Australia \\
\hline Euphorbia cyathophora Murray & Euphorbiaceae & Shrub & Tropical America \\
\hline Furcraea foetida (L.) Haw. & Agavaceae* & Shrub & Tropical America \\
\hline Galinsoga parviflora Cav. & Asteraceae & Herb & Tropical America \\
\hline Hibiscus mutabilis L. & Malvaceae & Shrub & China \\
\hline Impatiens balsamina $\mathrm{L}$. & Balsaminaceae & Herb & Tropical America \\
\hline Ipomoea nil (L.) Roth & Convolvulaceae & Climber & Tropical America \\
\hline Lantana camara L. var. aculeata L. & Verbenaceae & Shrub & Tropical America \\
\hline Lantana wightiana Wall ex Gamble & Verbenaceae & Shrub & Tropical America \\
\hline Ludwigia adscendens L. & Onagraceae & Shrub & Tropical America \\
\hline Ludwigia octovalvis Jacq. & Onagraceae & Herb & Tropical Africa \\
\hline Mimosa pudica L. & Mimosaceae & Herb & Brazil \\
\hline Monochoria vaginalis (Burm.f.) C.Presl ex Kunth & Pontederiaceae* & Herb & Tropical America \\
\hline Nicandra physalodes (L.) Gaertn. & Solanaceae & Herb & Tropical America \\
\hline Oxalis corniculata L. & Oxalidaceae & Herb & Europe \\
\hline Oxalis latifolia Kunth. & Oxalidaceae & Herb & Tropical America \\
\hline
\end{tabular}


Table 1. Cntd....

\begin{tabular}{llll}
\hline Botanical Name & Family & Habit & Native region \\
\hline Panicum maximum Jacq. & Poaceae* & Herb & Tropical Africa \\
Parthenium hysterophorus L. & Asteraceae & Shrub & North America \\
Passiflora subpeltata Ortega & Passifloraceae & Climber & Tropical America \\
Pistia stratiotes L. & Araceae* & Herb & Tropical America \\
Plantago erosa Wall. & Plantaginaceae & Herb & Euro-Asia \\
Psidium guajava L. & Myrtaceae & Tree & Tropical America \\
Ricinus communis L. & Euphorbiaceae & Shrub & Tropical America \\
Rubus ellipticus Smith & Rosaceae & Shrub & Tropical America \\
Solanum pseudocapsicum L. & Solanaceae & Shrub & Tropical America \\
Solanum seaforthianum Andrews & Solanaceae & Climber & Tropical America \\
Spergula arvensis L. & Caryophyllaceae & Herb & Europe \\
Turnera ulmifolia L. & Turneraceae & Herb & Tropical America \\
Typha angustata Bory and Chaub & Typhaceae* & Herb & Tropical America \\
Verbascum thapsus L. & Scrophulariaceae & Herb & Mediterranean Region \\
Verbena bonariensis L. & Verbenaceae & Herb & Tropical America \\
\hline Tote: & & &
\end{tabular}

Note: ${ }^{*}=$ Monocot families; Others are Dicots.

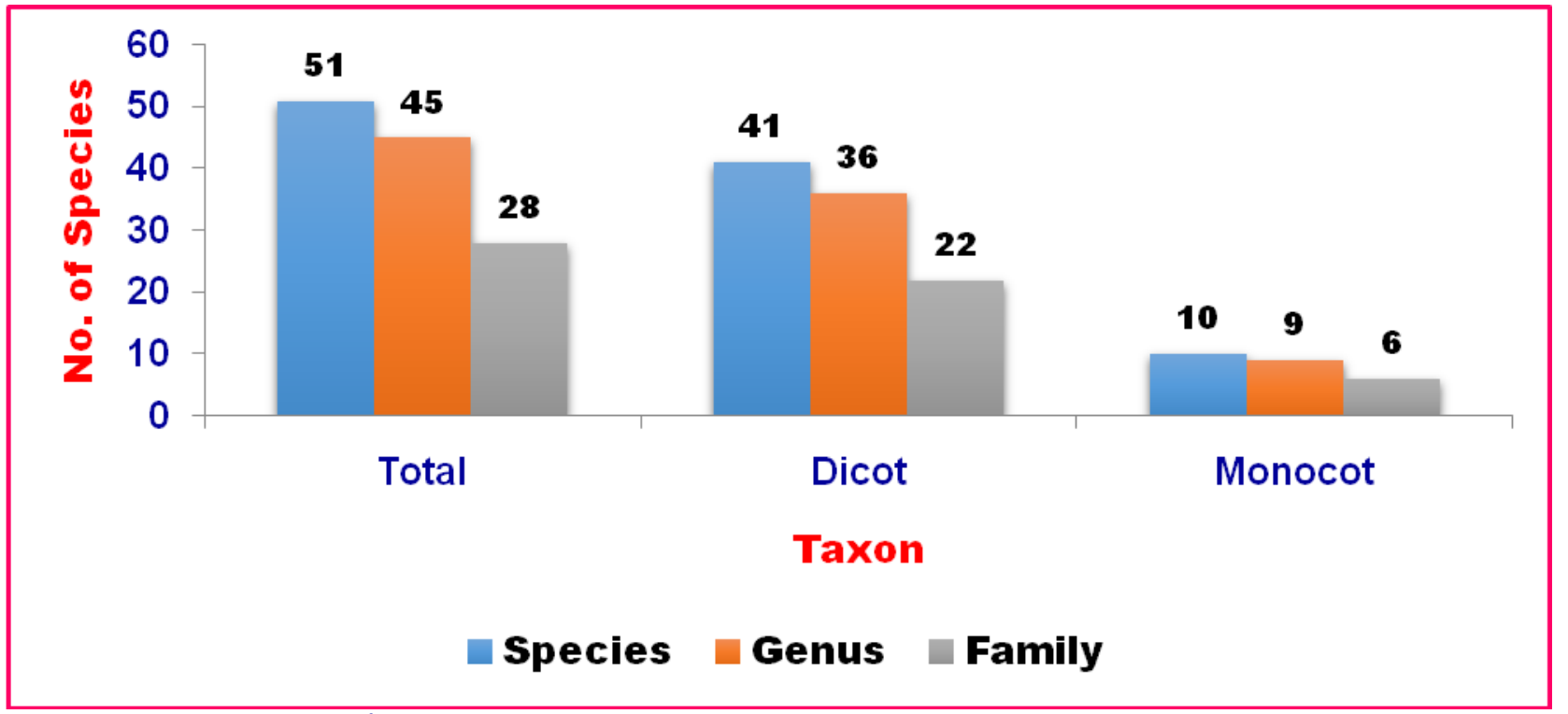

Fig. 1: Number of alien species recorded from the study site.

Of dicotyledons, Asteraceae (15.68\%) was found to be dominant and largest family comprising 8 species. Myrtaceae, Solanaceae and Verbenaceae (5.89\% each) shared the second largest family status; they were represented by 3 species and 13 families were represented by single species (each $1.96 \%$ each) (Table 2; Fig. 2). In case of the alien plants recorded under dicots, Eucalyptus, Lantana, Ludwigia, Oxalis and Solanum were represented by 2 species and which were found to be the dominant genus and the rest of the 31 genus were represented as monospecific genera (Table 1).

In case of monocotyledons, Poaceae (5.89\%) was recorded as dominant family with 3 species followed by Agavaceae and Cyperaceae (3.92\%) and they were found to be second dominant family comprising 2 species and rest of the 3 families (Araceae, Turneraceae and Typhaceae) were represented by single species (1.96\% each) (Table 2; Fig. 3). Among the alien plants recorded under monocots, Cyperus was represented by 2 species and it was found to be the dominant genus and the rest of the 8 genus were represented as monospecific genera (Table 1).

Regarding the habits of the alien plant species recorded, herbs (28 species) were found to be more in number than shrubs (15 species) followed by trees ( 5 species) and climbers (3 species). In 
the case of dicotyledons, among 41 species, 20 species were found to be as herbs, 13 species were found to be shrubs, 5 species were as trees and 3 species as climbers. In case of monocotyledons, 8 species of herbs and 2 species of shrubs, totally 10 species were recorded. There were neither climbers nor trees recorded in monocots (Table 1; Fig. 4).

Table 2. List of families with number of genus and species of alien plants.

\begin{tabular}{|c|c|c|c|}
\hline Family Name & No. of Genus & No. of Species & \% of total Species \\
\hline Agavaceae* & 2 & 2 & 3.92 \\
\hline Amaranthaceae & 1 & 1 & 1.96 \\
\hline Araceae* & 1 & 1 & 1.96 \\
\hline Asclepiadaceae & 1 & 1 & 1.96 \\
\hline Asteraceae & 8 & 8 & 15.68 \\
\hline Balsaminaceae & 1 & 1 & 1.96 \\
\hline Betulaceae & 1 & 1 & 1.96 \\
\hline Brassicaceae & 1 & 1 & 1.96 \\
\hline Caryophyllaceae & 1 & 1 & 1.96 \\
\hline Chenopodiaceae & 1 & 1 & 1.96 \\
\hline Convolvulaceae & 1 & 1 & 1.96 \\
\hline Cyperaceae* & 1 & 2 & 3.92 \\
\hline Euphorbiaceae & 2 & 2 & 3.92 \\
\hline Malvaceae & 1 & 1 & 1.96 \\
\hline Mimosaceae & 2 & 2 & 3.92 \\
\hline Myrtaceae & 2 & 3 & 5.89 \\
\hline Onagraceae & 1 & 2 & 3.92 \\
\hline Oxalidaceae & 1 & 2 & 3.92 \\
\hline Passifloraceae & 1 & 1 & 1.96 \\
\hline Plantaginaceae & 1 & 1 & 1.96 \\
\hline Poaceae* & 3 & 3 & 5.89 \\
\hline Pontederiaceae* & 1 & 1 & 1.96 \\
\hline Rosaceae & 2 & 2 & 3.92 \\
\hline Scrophulariaceae & 2 & 2 & 3.92 \\
\hline Solanaceae & 2 & 3 & 5.89 \\
\hline Turneraceae & 1 & 1 & 1.96 \\
\hline Typhaceae* & 1 & 1 & 1.96 \\
\hline Verbenaceae & 2 & 3 & 5.89 \\
\hline Total & 45 & 51 & 100 \\
\hline
\end{tabular}

There are number of studies have been strongly confirmed that the members of Asteraceae were found more among alien species. It includes invasive plant species occurring in Boluvampatti Forest Range located at Southern Western Ghats (Aravindhan and Rajendran, 2014), alien species habiting in Thiruvallur district (Udayakumar et al., 2014), invasive flora of Valley district of Manipur (Singh et al., 2015).

By the present investigation also, it was documented that the family Asteraceae was represented with large number of species in study stream. It was stated that Asteraceae is one of the largest flowering plant families in the world. With large number of seeds and parachute mechanisms the members of Asteraceae easily established their life on wide range of climatic conditions (Raghubanshi et al., 2005)

Regarding the native region of alien species recorded, 32 species (62.75\%) were belonging to Tropical America, 3 species (5.89\%) were belonging to Europe, 2 species (3.92\% each) from 
China, South-East Asia, Tropical Africa and Tropical Australia respectively and 1 species (each of 1.96\%) from Africa, America, Australia, Brazil,
Euro-Asian, Mediterranean region, North America and South-East Africa, respectively (Table 1; Fig. 5).

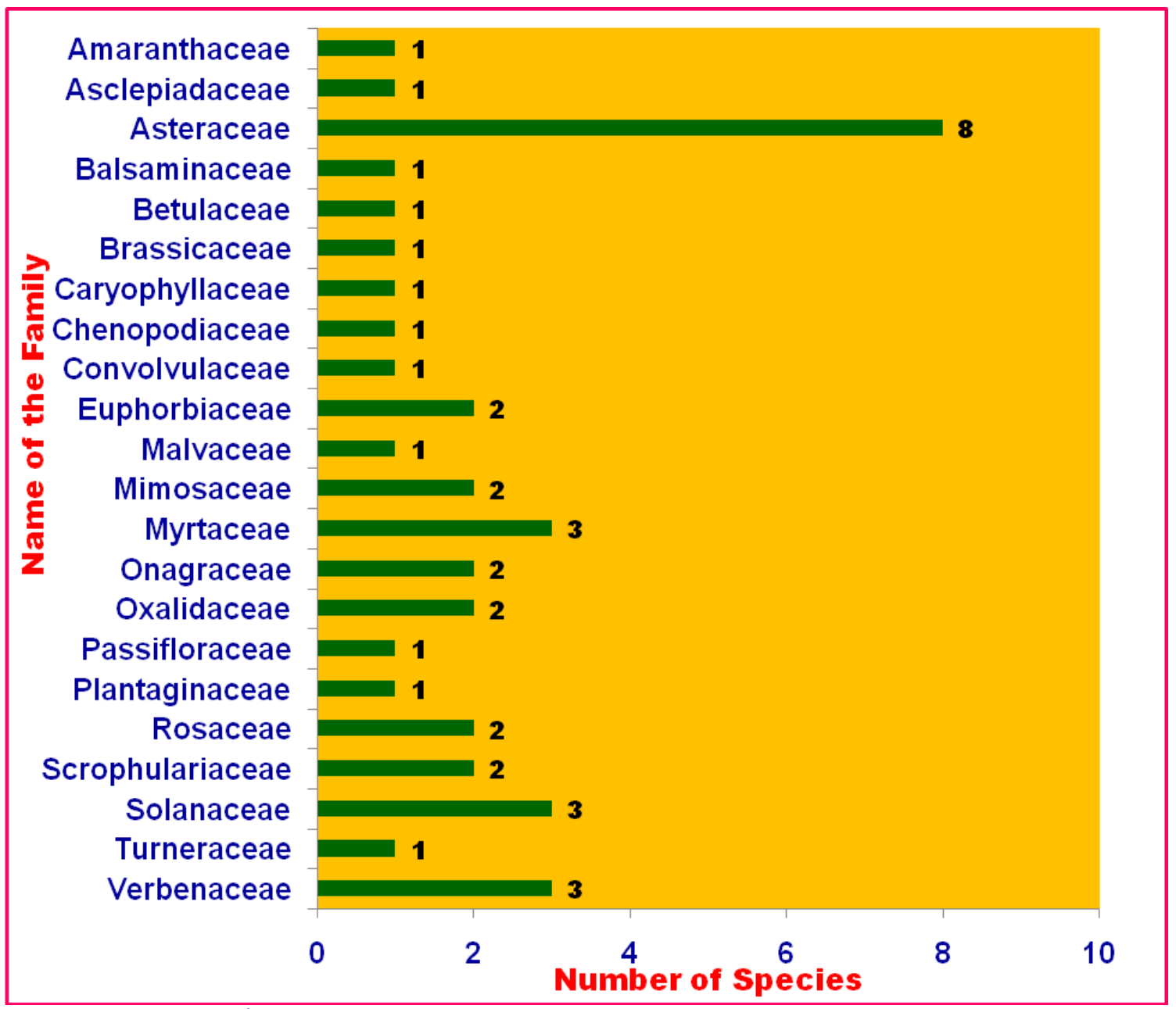

Fig.2: Number of alien species recorded with dicot families.

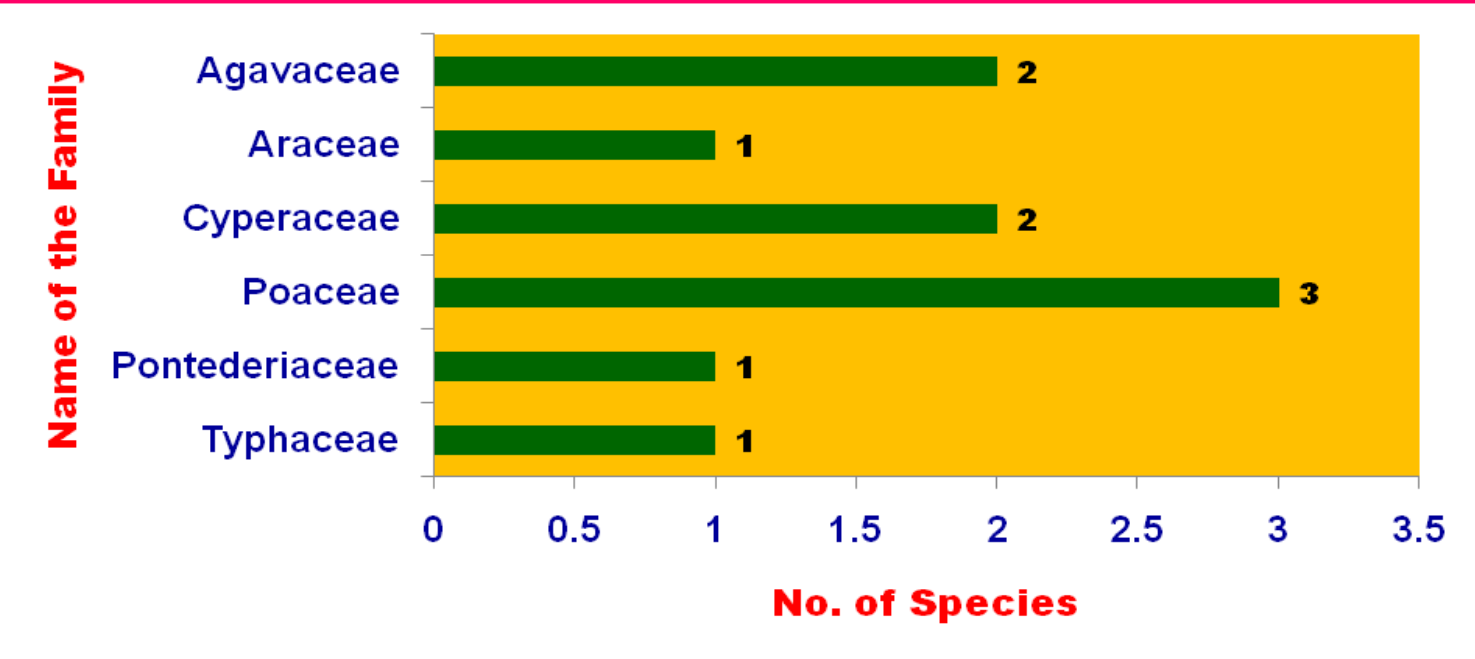

Fig.3: Number of alien species recorded with monocot families. 


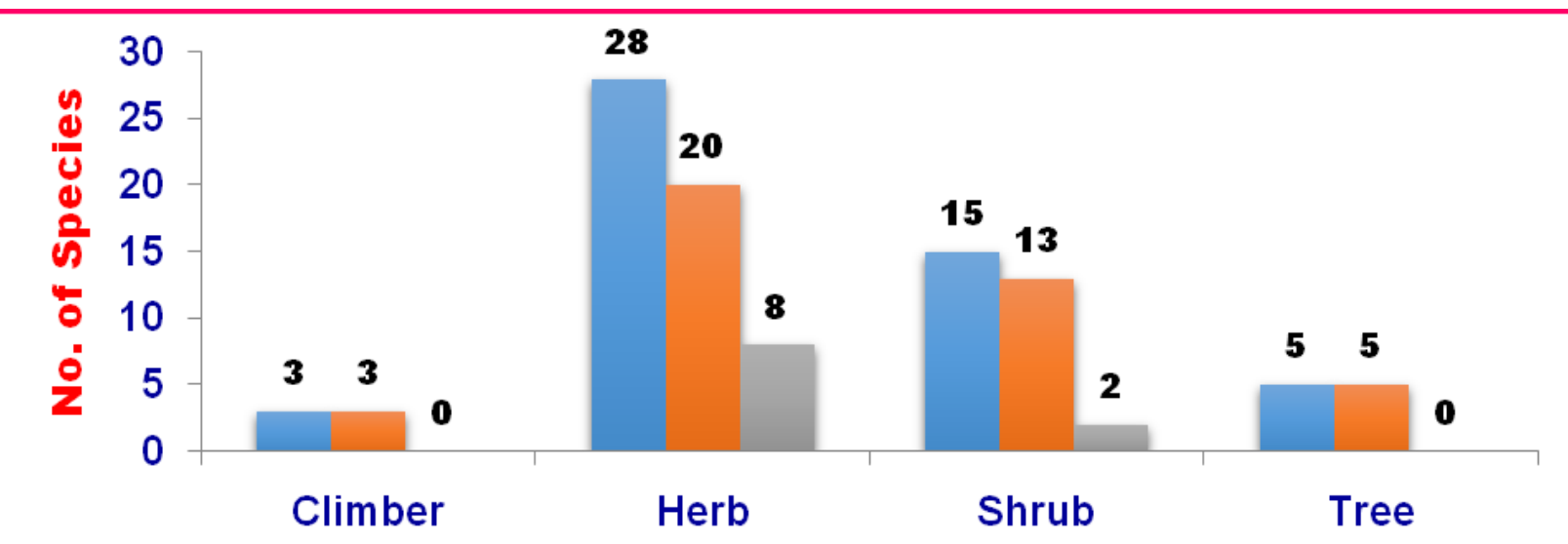

Taxon

Total Dicot Monocot

Fig.4: Number of alien species recorded among various habits.

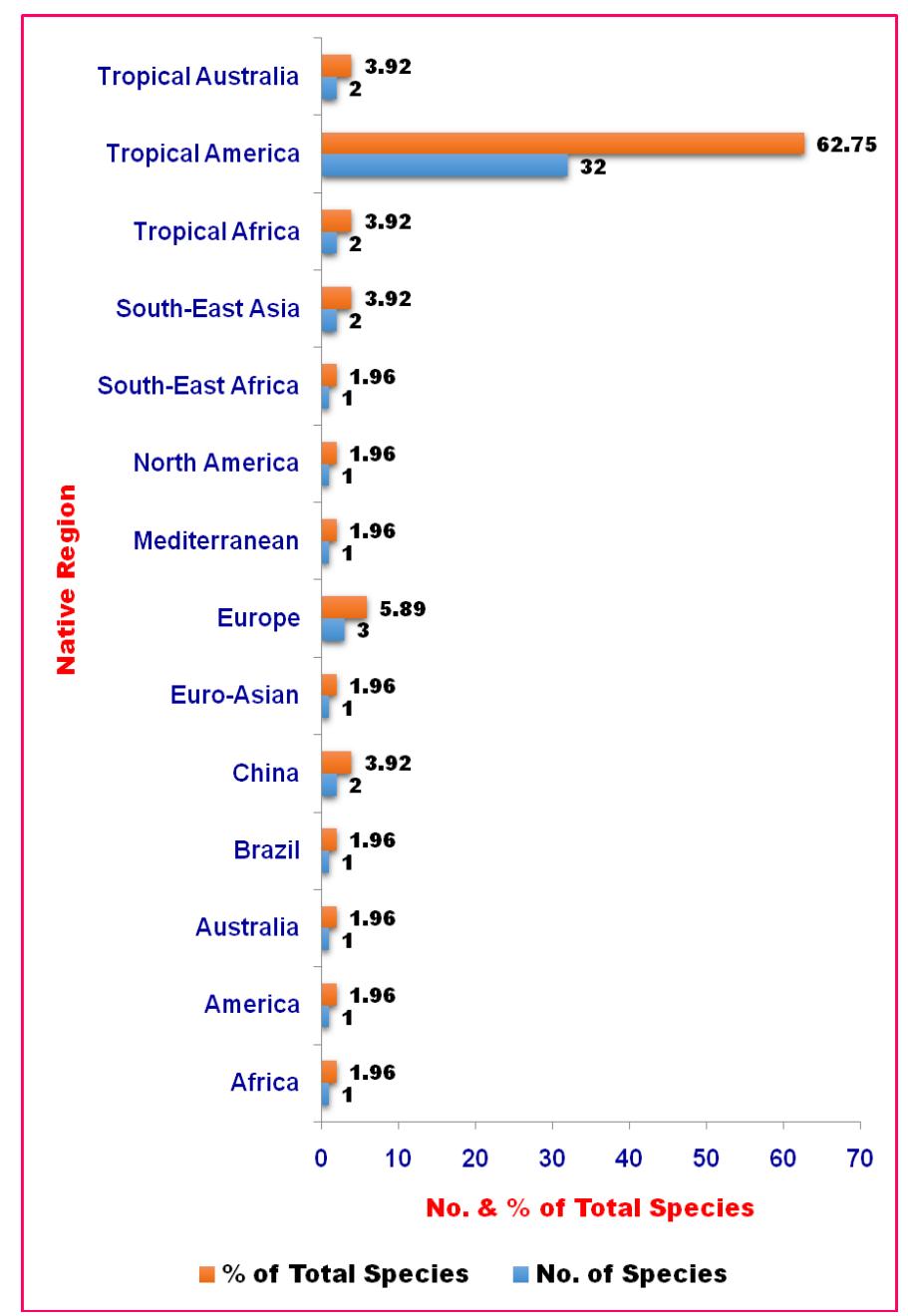

Fig.5: Native region contribution of alien species.

\section{Conclusion}

The impact of invasiveness created by these alien species should controlled by planting native species into the natural forest area.

\section{Conflict of interest statement}

Authors declare that they have no conflict of interest.

\section{References}

Aravindhan, V., Rajendran, A., 2014. Diversity of invasive plant species in Boluvampatti forest range, the Southern Western Ghats, India. AmEurasian. J. Agri. Environ. Sci. 14(8), 724-731.

Khanna, K.K., 2009. Invasive Alien Angiosperms of Uttar Pradesh. Biol. Forum. 1, 41-46.

Matthew, K.M., 1999. Flora of the Palni hills, Vols. 1 - 3. The Rapinat herbarium, St. Joseph's College, Tiruchirappalli, Tamil Nadu.

Narasimhan, D., 2006. Flora of Tamil Nadu - a database. ENVIS publication, Chennai, Tamil Nadu. www.tnenvis.nic.in.

Raghubanshi, A.S., Rai, L.C., Gaur J.P., Singh, J.S., 2005. Alien invasive species and biodiversity in India. Curr. Sci. 88, 539-540.

Richardson, D.M., Pysek, P., Rejmanek, M., Barbour, M.G., Panetta, F.D., West, C.J., 2000. Naturalization and invasion of alien plants: 
Concepts and definitions. Diver. Distrib. 6, 93107.

Sharma, G.P., Singh J.S.,Raghubanshi A.S., 2005. Plant invasions: emerging trends and future implications. Curr. Sci. 88, 726-734.

Simberloff, D., Parker, I.M.,Windle, P.M., 2005. Introduced species policy, management and future implications. Curr. Sci. 88, 726-734.
Singh, B., Das, A.K., Singh, P.K., 2015. Study of alien and invasive flora of valley district of Manipur and their control. Int. J. Innov. Res. Sci\& Tech. 1(12), 616-626.

Udayakumar, M., Bharathidasan, E.,Sekar, T., 2014. Invasive alien flora of Thiruvallur district, Tamil Nadu, India. Schol. Acad. J. Biosci. 2(4), 295-306.

\section{How to cite this article:}

Venkadeswaran, P., Suresh, K., Vasudevan, N., 2019. Invasive flora of Poondi stream, Kodaikanal, Tamil Nadu. Int. J. Curr. Res. Biosci. Plant Biol. 6(1), 12-18. doi: https://doi.org/10.20546/ijcrbp.2019.601.003 